\title{
Environmental issues and anthropic pressures in coastal aquifers: a case study in Southern Latium Region
}

\section{Aspetti ambientali e pressioni antropiche negli acquiferi costieri: un caso di studio nel Lazio Meridionale}

Giuseppe Sappa, Francesco Maria De Filippi, Flavia Ferranti, Silvia Iacurto

\begin{abstract}
Riassunto: L'intrusione salina è, ad oggi, uno dei principali problemi nella gestione della qualità dell'acqua potabile, specialmente per quelle aree costiere in cui l'urbanizzazione sta notevolmente aumentando. Infatti, in quei paesi caratterizzati da una vasta fascia costiera, come l'Italia, l'elevata domanda idropotabile può portare a uno sfruttamento incontrollato delle acque sotterranee nelle falde acquifere costiere. Durante l'estate 2017, un grave evento siccitoso ha colpito l'intero territorio italiano, in particolare la parte meridionale del Lazio. Al fine fronteggiare eventuali prossime crisi idriche, il gestore del servizio idrico integrato (Acqualatina S.p.a.) ha pianificato la realizzazione di un campo pozzi nell'area denominata " 25 Ponti", che fa parte del comune di Formia ed è a circa 500 metri di distanza dalla costa. Da settembre 2017 a dicembre 2017, il pozzo "Tulliola” è stato completato e utilizzato con portate di emungimento crescenti al fine di monitorare gli effetti dello sfruttamento delle acque sotterranee in questo acquifero carsico costiero. L'obiettivo di questo lavoro è presentare i primi risultati di queste attività di monitoraggio, svolte dal Dipartimento di Ingegneria Civile, Edile e Ambientale (DICEA) dell'Università Sapienza di Roma, al fine di valutare il tasso di salinizzazione delle acque sotterranee causato da un eventuale fenomeno di intrusione salina nell'area di studio.
\end{abstract}

Keywords: coastal aquifers, groundwater, salinization, seawater intrusion, monitoring.

Parole chiave: acquiferi costieri, acque sotterranee, salinizzazione, intrusione marina, monitoraggio.

Giuseppe SAPPA 棒"

Department of Civil, Building and Environmental Engineering (DICEA) Sapienza University of Rome

via Eudossiana 18, 00184 Rome, Italy

giuseppe.sappa@uniroma1.it

Francesco Maria DE FILIPPI

Flavia FERRANTI

Silvia IACURTO

Department of Civil, Building and Environmental Engineering (DICEA)

Sapienza University of Rome

Ricevuto/Received: 14 January 2019-Accettato/Accepted: 14 March 2019 Pubblicato online/Published online: 29 March 2019

This is an open access article under the CC BY-NC-ND license:

http://creativecommons.org/licenses/by-nc-nd/4.0/

(C) Associazione Acque Sotterranee 2019
Abstract: Saline intrusion is one of the main problems in the drinking water quality management, especially for those coastal areas in which urbanization is seriously increasing. In fact, in some countries with an extensive coastline, such as Italy, the high drinking water demand can lead to an uncontrolled groundwater exploitation of coastal aquifers. During summer 2017, a severe drought event affected the entire Italian territory, including the study area located in the southern part of Latium Region. In order to overcome future water crisis, the water-supply agency (Acqualatina S.p.a.) has planned the realization of a wellfield in the "25 Ponti Area", belonging to the Municipality of Formia and about $500 \mathrm{~m}$ far away from the coastline. From September 2017 to December 2017, Tulliola Well has been completed and used at increasing flow rates to monitoring the effects of groundwater exploitation on this karst coastal aquifer. The aim of this paper is to present the first results of the monitoring activities, carried out by the Department of Civil, Building and Environmental Engineering (DICEA) of Sapienza University of Rome, in order to evaluate the rate of groundwater salinization due to a possible seawater intrusion phenomenon in the study area.

\section{Introduction}

Water management is one of the current global challenges due to the role played by freshwater as a resource for sustaining life and human needs. In many parts of the world increasing urbanization and improvement of living conditions have led to a growth of drinking water demand, causing in some cases an uncontrolled groundwater exploitation of coastal aquifers (Capaccioni et al. 2005; Sappa and Luciani 2015; Najaib et al. 2017). Intensive groundwater withdrawals from coastal aquifers may decrease freshwater outflows to the sea, lower the water table, and cause the encroachment of seawater inland, resulting in a worsening of groundwater quality (Alfarrah and Walraevens 2018). Therefore, seawater intrusion is an active process, driven by changes to hydrogeologic system, which trigger substantial groundwater quality changes (Sappa et al. 2015; Barbieri et al. 2017; Bakalowicz 2018). Several water geochemical indicators and diagrams are mainly used in literature to investigate potential seawater intrusion in coastal aquifers (Kelly 2006; Giménez-Forcada 2010; Sajil Kumar 2016; Jorreto et al. 2017). A sustainable groundwater exploitation is an important environmental issue in this context, because the intensity of these events depends on several factors as the pumping rates, the well field location and design, as well as the geometry, and the hydrogeological parameters of the pumped aquifer (Alfarrah and Walraevens 2018). In summer 2017, a severe drought event affected 
the Italian territory (IRSA 2017) with serious impact on population and inconveniences for local water supply agencies. In the municipality of Formia (Latina Province), the local water supply agency, because of the decreasing flow rates supplied by Mazzoccolo and Capodacqua di Spigno springs, planned and built a well field in the " 25 Ponti Area" in order to handle future water crisis. Groundwater monitoring activities performed in the " 25 ponti" area will support the local water supply agency in its decisions aimed at sustainable water resource management, avoiding groundwater salinization by seawater intrusion.

\section{Site description}

The study area is located in the western part of the Municipality of Formia, in the south-eastern part of Latium Region (Fig. 1), about $500 \mathrm{~m}$ far away from the coastline. Formia is a highly urbanized city with recognized watershortage challenges and high dependence on groundwater resources. A fractured, heterogeneous aquifer lies below the inhabited area. The geological setting (Baldi et al. 2005) is characterized by Pliocene sea deposits overlapping detritalorganogenic limestone and calcareous-dolomitic rocks (platform deposits).

Permeability characteristics and the extent of the Cretaceous limestone complex and the underlying Jurassic dolomite complex allows the presence of important aquifers. Underground circulation takes place mainly in the limestone, while dolomites act as the bottom boundary of the groundwater flow (Sappa et al. 2018). In the study area, the aquifer is made up of a fractured and karst micritic limestone with interbedded clay levels (about $8 \mathrm{~m}$ ), a calcareous breccia (about $30 \mathrm{~m}$ ) and, at the bottom, a micritic limestone with a thickness of several hundred meters (Fig. 2).

The aquifer is characterized by elevated values of transmissivity and infiltration rate due to a well-developed karst (Sappa et al. 2015). Currently only two wells have been completed in the "25 Ponti" area (Tab. 1).

Tab. 1 - The location of well water sampling survey.

Tab. 1 - Localizzazione dei punti di campionamento.

\begin{tabular}{|l|l|l|l|l|l|}
\hline Name & ID & Latitude & Longitude & $\begin{array}{l}\text { Elevation } \\
(\mathrm{m} \text { a.s.l. })\end{array}$ & $\begin{array}{l}\text { Depth } \\
(\mathrm{m})\end{array}$ \\
\hline $\begin{array}{l}\text { Tulliola } \\
\text { well }\end{array}$ & TUL & $41^{\circ} 15^{\prime} 8.21^{\prime \prime}$ & $13^{\circ} 35^{\prime} 2.23^{\prime \prime}$ & 20 & 55 \\
\hline $\begin{array}{l}\text { Terenzia } \\
\text { well }\end{array}$ & TER & $41^{\circ} 15^{\prime} 8.04 ”$ & $13^{\circ} 34^{\prime} 59.06^{\prime \prime}$ & 20 & 90 \\
\hline
\end{tabular}

\begin{tabular}{|c|c|c|}
\hline \multicolumn{3}{|c|}{ LEGEND } \\
\hline $\begin{array}{l}\text { Sandy-loamy deposits with } \\
\text { limestone pebbles }\end{array}$ & $\begin{array}{l}\text { Breccia withclasts } \\
\text { limestone }\end{array}$ & $\Longrightarrow$ Groundwater flow \\
\hline $\begin{array}{l}\text { Fractured and karst micritic limestone } \\
\text { with interbedded clay levels }\end{array}$ & Micritic limestone & Water table level \\
\hline
\end{tabular}
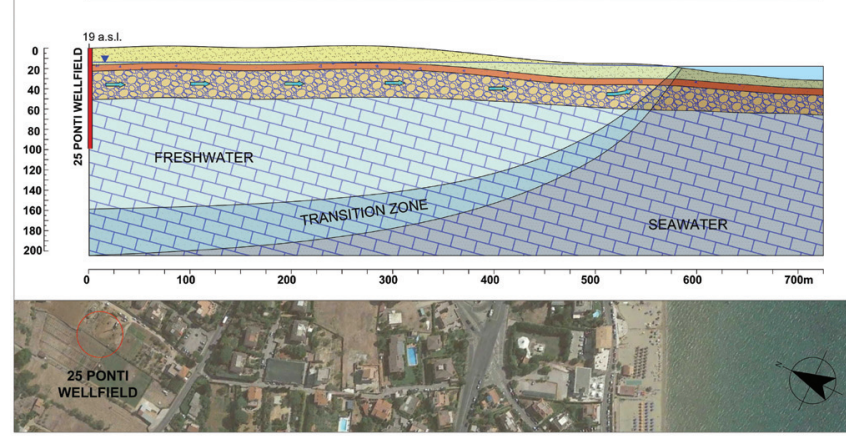

Fig. 2 - Seawater-freshwater interface in the study area.

Fig. 2 - Interfaccia acqua dolce - acqua salata nell'area di studio.

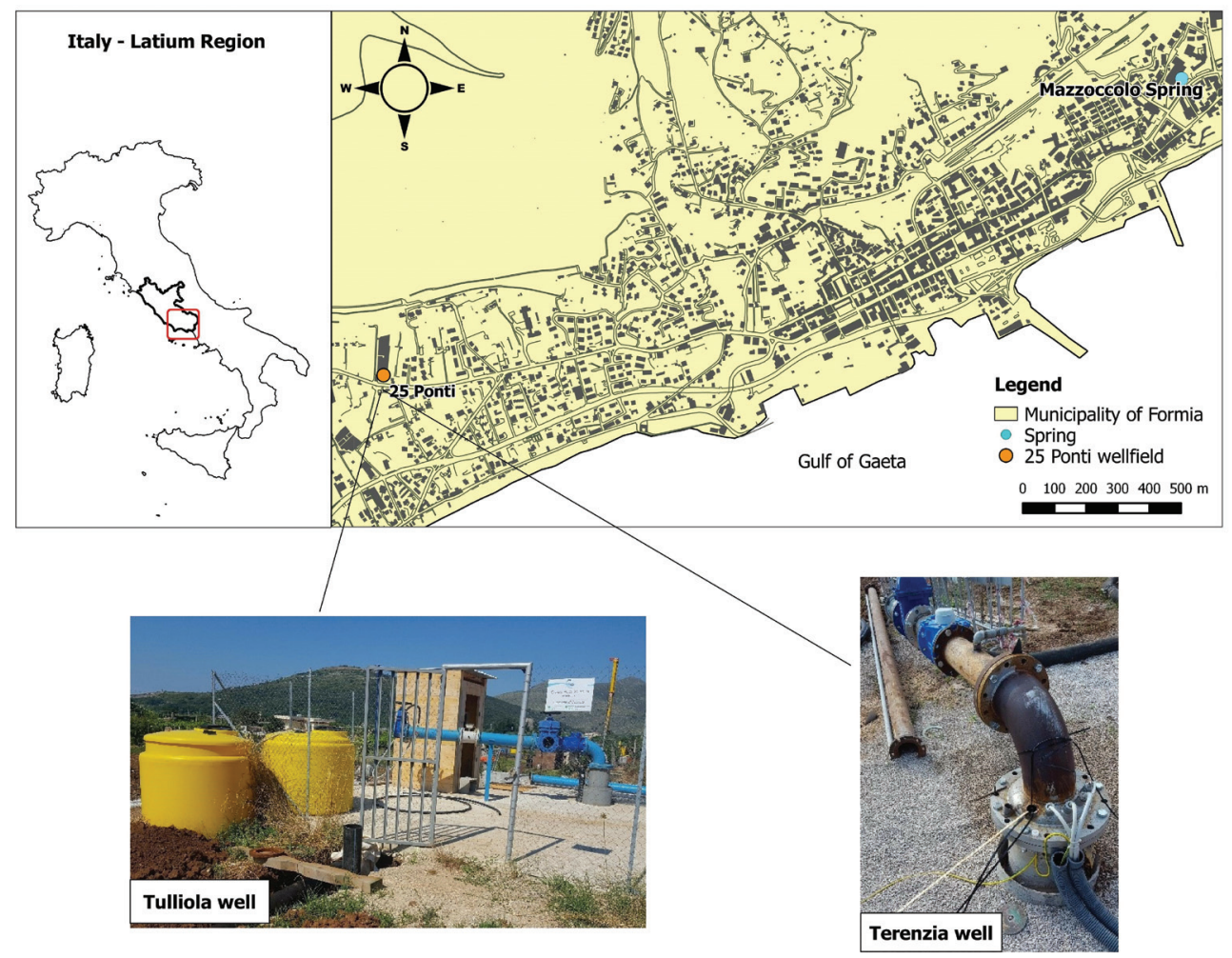

Fig. 1 - Study area and localization of Tulliola and Terenzia wells.

Fig. 1 - . Area di studio e localizzazione dei pozzi Tulliola e Terenzia. 


\section{Materials and Methods}

Groundwater monitoring activities were carried out from August 2017 to July 2018. Eighteen (18) groundwater samples were collected from Tulliola and Terenzia wells (Table 2): sixteen water samples were collected from August to November 2017 from Tulliola well, during a long-term exploitation period, whereas two samples were collected in June 2018 from Terenzia well, during the first pumping tests. The chemical composition was determined using standard analytical methods (APHA 1995). Analyses of major cations and anions were carried out by the laboratory of the local water-supply agency, using a Dionex ICS 1000 Ion Chromatograph (Tab. 2).

\section{Results and discussion}

The geochemical data analysis show an increasing trend of electrical conductivity (EC) due to the rise of some ions concentrations, such as chloride. For Tulliola well, EC values range from $607 \mu \mathrm{S} / \mathrm{cm}$ to $858 \mu \mathrm{S} / \mathrm{cm}$, respectively at the beginning and at the end of the long-term exploitation period. $\mathrm{Cl}^{-}$content also increases from 44.7 to $136.7 \mathrm{mg} / \mathrm{l}$ from August 2017 to November 2017, proportionally to the EC increasing trend (Tab. 2).

This EC trend seems to be related to the flow rates exploited from Tulliola well, which have been increased from $17 \mathrm{l} / \mathrm{s}$ (September 2017) to $37 \mathrm{l} / \mathrm{s}$ (October-December 2017). Therefore, pumping rates would play a key role in the observed changes in groundwater salinity (Fig. 3).

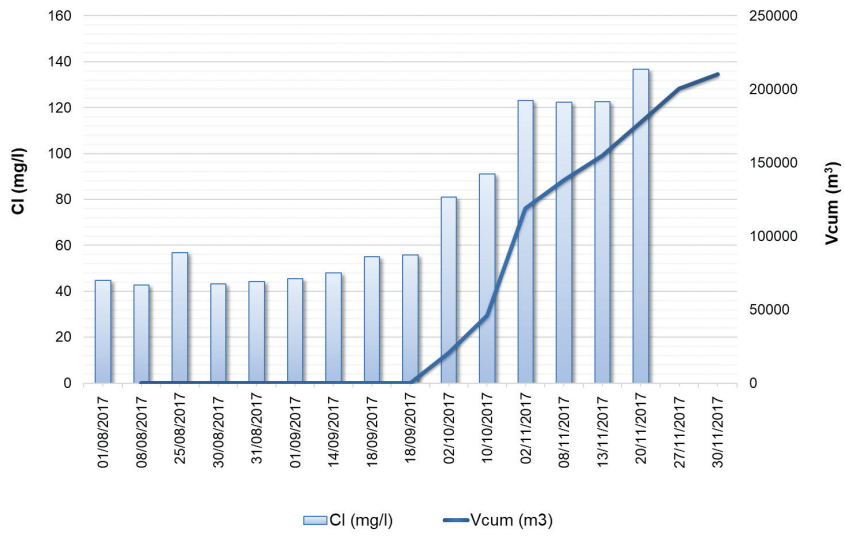

Fig. 3 - Comparison between $\mathrm{Cl}^{-}$concentrations and water cumulative volume from Tulliola well.

Fig. 3 - Confronto tra le concentrazioni di $\mathrm{Cl}^{-}$e i volumi cumulati prelevati dal pozzo Tulliola.

Terenzia well samples show EC values above $1100 \mu \mathrm{S} /$ $\mathrm{cm}$ and higher chloride concentrations (up to $218 \mathrm{mg} / \mathrm{l}$ ) compared to Tulliola outcomes (Tab. 2), probably due to the greater depth of the well (Tab. 1). The potential groundwater salinization has been investigated by the analysis of the $\mathrm{Na}^{+} / \mathrm{Cl}^{-}$ionic ratio. All groundwater samples, except TUL_01, show $\mathrm{Na}^{+} / \mathrm{Cl}^{-}$molar ratios lower than the seawater value $(0.88)$. The decreasing trend over time, as the groundwater exploitation increases, may suggest a possible seawater encroachment (Fig. 4). The lowest values of this ratio may be attributed to depletion of $\mathrm{Na}^{+}$, probably caused by cation

Tab. 2 - Results of chemical-physical analysis for groundwater samples collected from Tulliola and Terenzia wells.

Tab. 2 - Risultati delle analisi chimico-fisiche per i campioni di acqua sotterranea raccolti nei pozzi Tulliola e Terenzia.

\begin{tabular}{|c|c|c|c|c|c|c|c|c|c|c|}
\hline ID & $\begin{array}{c}\text { Date } \\
{[\mathrm{dd} / \mathrm{mm} / \text { yyyy }]}\end{array}$ & $\begin{array}{c}\mathrm{EC} \\
{[\mu \mathrm{S} / \mathrm{cm}]}\end{array}$ & $\begin{array}{c}\mathrm{Na}^{+} \\
{[\mathrm{mg} / \mathrm{l}]}\end{array}$ & $\begin{array}{c}\mathrm{K}^{+} \\
{[\mathrm{mg} / \mathrm{l}]}\end{array}$ & $\begin{array}{l}\mathrm{Ca}^{2+} \\
{[\mathrm{mg} / \mathrm{ll}]}\end{array}$ & $\begin{array}{l}\mathrm{Mg}^{2+} \\
{[\mathrm{mg} / 1]}\end{array}$ & $\begin{array}{c}\mathrm{Cl}^{-} \\
{[\mathrm{mg} / \mathrm{l}]}\end{array}$ & $\begin{array}{l}\mathrm{SO}_{4}{ }^{2-} \\
{[\mathrm{mg} / \mathrm{ll}]}\end{array}$ & $\begin{array}{l}\mathrm{NO}_{3}^{-} \\
{[\mathrm{mg} / \mathrm{l}]}\end{array}$ & $\begin{array}{l}\mathrm{HCO}_{3}^{-} \\
{[\mathrm{mg} / \mathrm{l}]}\end{array}$ \\
\hline TUL_01 & 01/08/2017 & 607 & 27.3 & 12.4 & 62.9 & 11.3 & 44.7 & 30.6 & 16.3 & 244.0 \\
\hline TUL_02 & 08/08/2017 & 661 & 19.6 & 3.1 & 86.3 & 12.9 & 42.8 & 27.8 & 17.6 & 475.8 \\
\hline TUL_03 & $25 / 08 / 2017$ & 661 & 29.9 & 1.8 & 88.6 & 15.7 & 56.8 & 27.2 & 14.8 & 353.8 \\
\hline TUL_04 & $30 / 08 / 2017$ & 644 & 20.5 & 1.0 & 83.3 & 12.5 & 43.3 & 32.3 & 17.4 & 317.2 \\
\hline TUL_06 & 01/09/2017 & 662 & 18.1 & 0.4 & 75.4 & 10.2 & 45.4 & 30.4 & 18.0 & 280.6 \\
\hline TUL_07 & $14 / 09 / 2017$ & 663 & 20.5 & 1.0 & 88.1 & 12.9 & 48.1 & 31.5 & 18.6 & 329.4 \\
\hline TUL_08 & $18 / 09 / 2017$ & 683 & 23.2 & 1.0 & 95.0 & 14.1 & 55.0 & 29.6 & 16.3 & 366.0 \\
\hline TUL_09 & $18 / 09 / 2017$ & 684 & 22.6 & 1.0 & 95.5 & 13.9 & 55.8 & 29.9 & 16.5 & 366.0 \\
\hline TUL_10 & $02 / 10 / 2017$ & 740 & 23.9 & 1.0 & 92.9 & 13.4 & 80.9 & 30.2 & 15.0 & 353.8 \\
\hline TUL_12 & $02 / 11 / 2017$ & 835 & 33.3 & 1.9 & 111.2 & 15.3 & 123.2 & 29.8 & 13.4 & 414.8 \\
\hline TUL_13 & 08/11/2017 & 843 & 32.4 & 1.5 & 112.5 & 16.4 & 122.2 & 30.2 & 13.3 & 427.0 \\
\hline TUL_14 & $13 / 11 / 2017$ & 835 & 32.4 & 1.4 & 113.1 & 16.0 & 122.6 & 29.9 & 13.1 & 427.0 \\
\hline TUL_15 & 20/11/2017 & 846 & 36.7 & 1.0 & 116.4 & 16.3 & 136.7 & 29.8 & 12.9 & 439.2 \\
\hline TUL_16 & $27 / 11 / 2017$ & 858 & 35.6 & 0.3 & 114.4 & 14.6 & 137.3 & 30.8 & 13.3 & 427.0 \\
\hline TER_01 & 09/07/2018 & 1102 & 55.0 & 1.4 & 133.3 & 32.9 & 196.0 & 69.2 & 28.5 & 573.4 \\
\hline TER_02 & $11 / 07 / 2018$ & 1146 & 58.0 & 2.0 & 140.1 & 34.1 & 218.3 & 69.6 & 27.6 & 597.8 \\
\hline
\end{tabular}


exchange occurring in the clay levels interbedded in limestone (Alfarrah and Walraevens 2018). These results are supported by the identification of the groundwater hydrochemical facies obtained by plotting the water samples in a Piper tri-linear diagram modified for salinization processes (Kelly 2006). All water samples fall in the freshwater field, but a trend toward seawater is evident (Fig. 5).

The effect of groundwater withdrawals on salinization is also pointed out by the Hydrochemical Facies Evolution

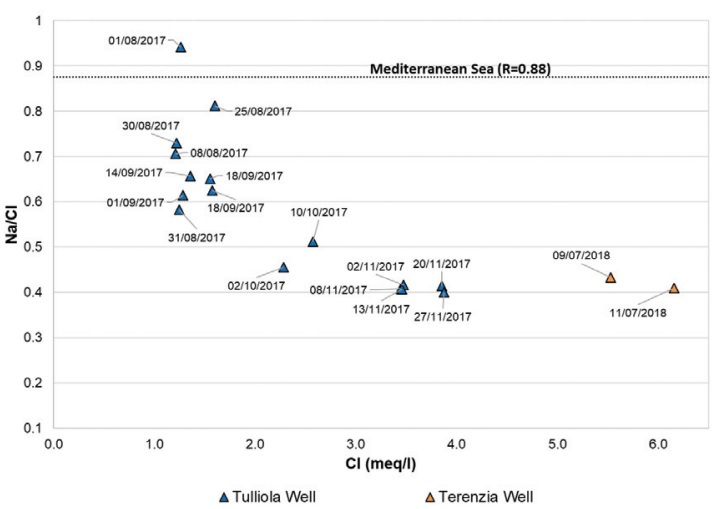

Fig. $4-\mathrm{Cl}^{-}$vs. $\mathrm{Na}^{+} / \mathrm{Cl}^{-}$ratio bivariate plot.

Fig. 4 - Diagramma binario $\mathrm{Cl}^{-}$vs. rapporto $\mathrm{Na}^{+} / \mathrm{Cl}^{-}$. diagram (HFE-D), proposed by Giménez-Forcada (GiménezForcada and Sànchez San Romàn 2015). This diagram has been created to highlight the main processes occurring in coastal aquifers, as seawater intrusion evolution. In figure 6 all groundwater samples are plotted on the right and below the seawater-freshwater mixing line, falling in the field of $\mathrm{Mg}-\mathrm{Ca}-\mathrm{HCO}_{3}$ facies.

In order to investigate the freshwater-seawater mixing in the study area, a groundwater sample, collected from the main karst spring near the study area, Mazzoccolo Spring, (Sappa et al. 2015), was plotted in the HFE-D diagram, as freshwater end-member. The Mazzoccolo Spring sample and TUL_01 sample collected in $01 / 08 / 2017$, fall in the same position. Therefore Tulliola well water, collected before the exploitation, have the same characteristics of freshwater. Tulliola water samples collected in August 2017 fall along the mixing line, while the other samples show a trend towards $\mathrm{Ca}-\mathrm{MixHCO}_{3}$ composition (Fig. 6), highlighting a development of reverse exchange reactions, triggered by the increase in salinity due to the up-coning phenomenon. Water samples collected from Terenzia well are closer than Tulliola ones to the mixing line, suggesting the presence of a more mineralized water facies.

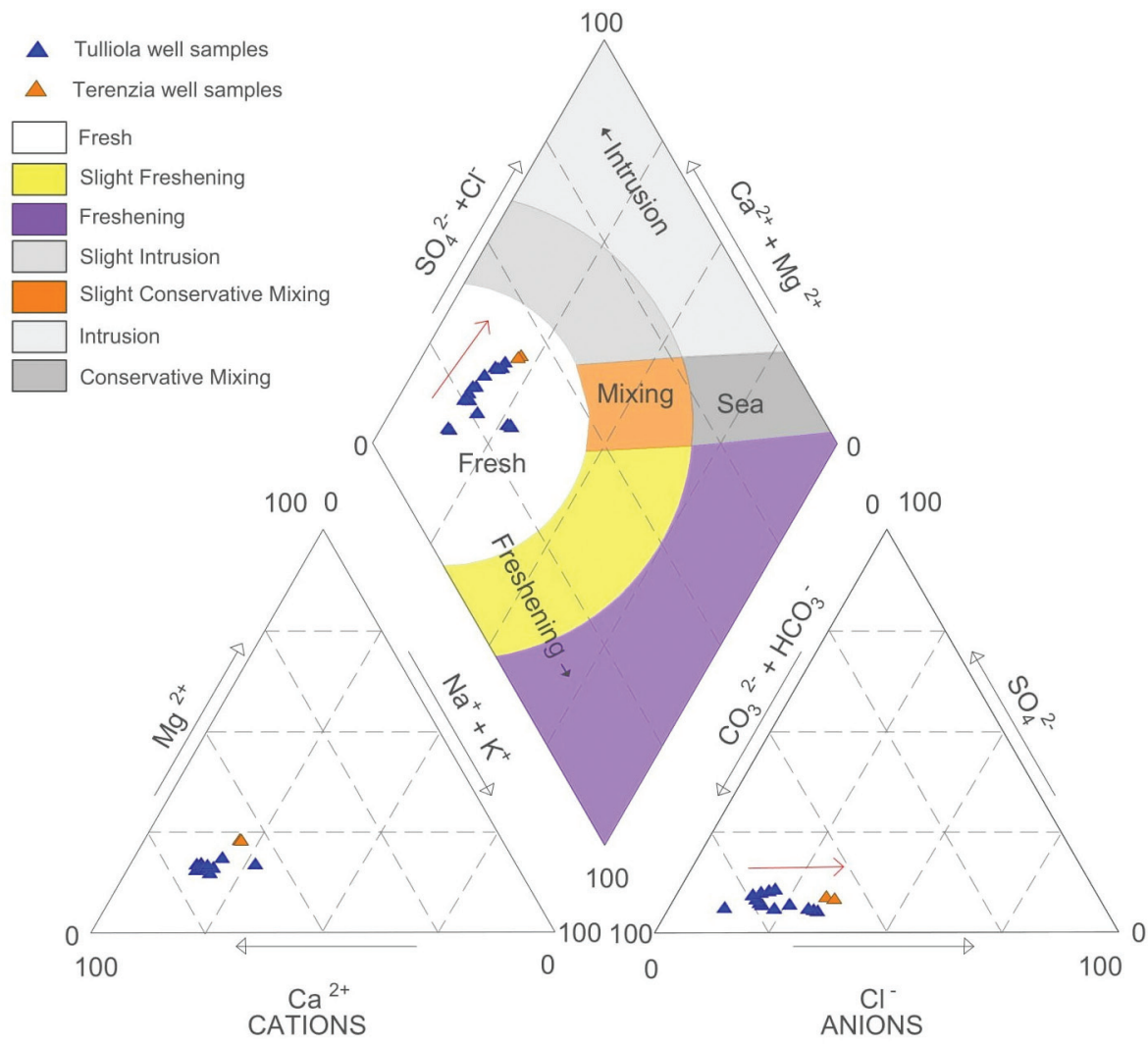

Fig. 5 - Piper Diagram of groundwater samples (modified by D. Kelly for saline intrusion evaluation, 2006).

Fig. 5 - Diagramma di Piper relativo ai campioni prelevati (modificato da D. Kelly per la valutazione dell'intrusione salina, 2006). 


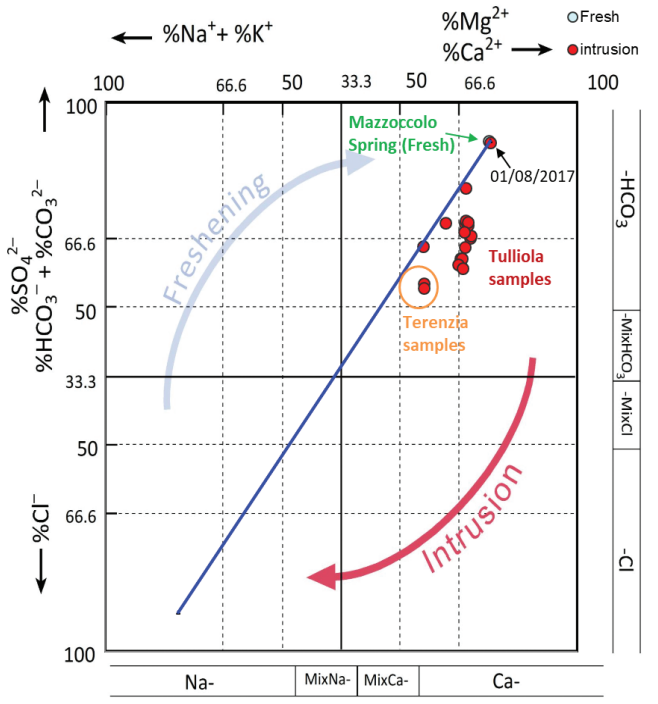

Fig. $6-\mathrm{Cl}^{-}$vs. $\mathrm{Na}^{+} / \mathrm{Cl}^{-}$ratio bivariate plot.

Fig. 6 - Diagramma binario $\mathrm{Cl}^{-}$vs rapporto $\mathrm{Na}^{+} / \mathrm{Cl}^{-}$.

\section{Conclusions}

First results of the coastal aquifer groundwater monitoring in the "25 Ponti area" (Municipality of Formia - Latina Province) have been discussed, based on groundwater analysis of several samples withdrawn from two wells (Tulliola and Terenzia wells).

Geochemical characterization has been used to evaluate seawater intrusion issues. The enrichment in some chemicals constituents highlights the potential triggering of groundwater salinization, due to water well withdrawals.

For Tulliola well water samples, $\mathrm{Na}^{+} / \mathrm{Cl}^{-}$ratios range from 0.39 to 0.94 , pointing out an ongoing seawater intrusion process. Moreover, a cation exchange is quite evident, considering the deficit of $\mathrm{Na}^{+}$and the surplus of $\mathrm{Ca}^{2+}$ with respect to the trend indicated by the freshwater-saline water mixing line.

The applied modified Piper diagram (Kelly 2005) shows a slight intrusion process in progress. The Hydrochemical Facies Evolution diagram (HFE-D), (Giménez-Forcada 2010), highlights a trend toward $\mathrm{Ca}-\mathrm{MixHCO}_{3}$ composition, due to the observed salinity increasing, which drives the development of reverse exchange reactions. This result is quite remarkable, since groundwater samples, collected before the beginning of well pumping, are very similar to the Mazzoccolo Spring water sample, which represents the freshwater-end member of the mixing line.

Future developments of the study could be the predisposition of:

- an early warning monitoring system;

- more detailed monitoring activities such as isotopic characterization $\left({ }^{2} \mathrm{H},{ }^{18} \mathrm{O},{ }^{87} \mathrm{Sr} /{ }^{86} \mathrm{Sr}\right)$ in the same sampling points;

- a groundwater hydrodynamic model extending the water level measurements to other wells present nearby the study area.

\section{REFERENCES}

Alfarrah N, Walraevens K (2018) Groundwater Overexploitation and Seawater Intrusion in Coastal Areas of Arid and Semi-Arid Regions. Water 10(22):143. doi:10.3390/w10020143.

APHA (1995) Standard methods for the examination of water and wastewater $19^{\text {th }}$ edn. APHA, Washington, DC.

Bakalowicz M (2018) Coastal Karst Groundwater in the Mediterranean: A resource to be preferably exploited onshore, not from karst submarine springs. Geosciences 8(7):258. doi:10.3390/geosciences8070258.

Baldi AM, Marzocchi A, Ricci F, Mencarini S, Vecellio L, Graziosi A, Di Mauro G (2005) La torbidità alle captazioni idropotabili dei Monti Aurunci "The turbidity of the Aurunci Mountains springs". Aquifer Vulnerability and Risk, $4^{\text {th }}$ Congress on the Protection and Management of Groundwater, Parma, Italy, 21-22-23 September 2005.

Barbieri M, Nigro A, Petitta M (2017) Groundwater mixing in the discharge area of San Vittorino Plain (Central Italy): geochemical characterization and implication for drinking uses. Environ Earth Sci 76(11). doi:10.1007/s12665-017-6719-1.

Capaccioni B, Didero M, Paletta C, Didero L (2005) Saline intrusion and refreshering in a multylayer coastal aquifer in the Catania Plain (Sicily, Southern Italy): dynamics of degradation processes according to the hydrochemical characteristics of groundwater. J Hydrol 307:1-16. doi:10.1016/j.jhydrol.2004.08.037.

Giménez-Forcada E (2010) Dynamic of Seawater Interface using Hydrochemical Facies Evolution Diagram (HFE-D). Groundwater 48(2):212-16 doi:10.1111/j.1745-6584.2009.00649.x.

Giménez-Forcada E, Sànchez San Romàn FJ (2015) An Excel Macro to Plot the HFE- Diagram to Identify Sea Water Intrusion Phases. Groundwater 53:319-824. doi:10.1111/gwat.12280.

Istituto di Ricerca sulle Acque (IRSA). Caratterizzazione climatica del regime pluviometrico nell'area del distretto idrografico dell'appennino centrale nel periodo 1951-2017: Report Regime Climatico, 2017. Available from: http://www.irsa.cnr.it/index.php/ita/ news/item/192-report-regime-climatico Accessed: March 2019.

Jorreto S, Sola F, Vallejos Á, Sánchez-Martos F, Gisbert J, Molinaì L, Rigol JP; Pulido-Bosch A (2017) Evolution of the geometry of the freshwater-seawater interface in a coastal aquifer affected by an intense pumping of seawater. Geogaceta 62:87-90

Kelly DJ (2006) Development of Seawater Intrusion Protection Regulations. Session 6, 1st SWIM-SWICA Joint Saltwater Intrusion Conference, Cagliari-Chia Laguna, Italy, September 24-29, 2006

Najaib S, Fadili A, Mehdi K, Riss J, Makan A (2017) Contribution of hydrochemical and geoelectrical approaches to investigate salinization process and seawater intrusion in the coastal aquifers of Chaouia, Morocco. J Contam Hydrol 198:24-36. doi:10.1016/j.jconhyd.2017.01.003.

Sajil Kumar PJ (2016) Deciphering the groundwater-saline water interaction in a complex coastal aquifer in South India using statistical and hydrochemical mixing models. Model. Earth Syst. Environ 194. doi:10.1007/s40808-016-0251-2

Sappa G, Ergul S, Ferranti F, Sweya LN, Luciani G (2015) Effects of seasonal change and seawater intrusion on water quality for drinking and irrigation purposes, in local aquifers of Dear Es Salaam, Tanzania. J Afr Earth Sci 105:64-84. doi:10.1016/j.jafrearsci.2015.02.007.

Sappa G, Ferranti F, Ergul S (2015) Environmental impact of a motorway tunnel project on an important karst aquifer in southern Latium Region: The case of Mazzoccolo Spring (Formia, Italy). In Engineering Geology for Society and Territory, 6:761-766.

Sappa G, Ferranti F, Iacurto S, De Filippi FM (2018) Effects of climate change on groundwater feeding the Mazzoccolo and Capodacqua di Spigno Springs (Central Italy): First quantitative assessments. SGEM GeoConference, 18(3.1): 219-226. doi: 10.5593/ sgem2018/3.1/S12.029.

Sappa G, Luciani L (2015) Sustainability of groundwater management in the coastal plain of Dar es Salaam (Tanzania). Rendiconti Online Società Geologica Italiana 35:264-267. doi:10.3301/ROL.2015.116. 